\title{
Kalibrasi Aplikasi Pengukur Tingkat Suara Berbasis iOS Dengan Perangkat Pengukur Tingkat Suara Digital Di Satuan Tingkat Tekanan Bunyi dBA
}

\author{
Wandy Wandy, Muhammad Agni Catur Bhakti \\ Sampoerna University \\ wandy.wandy@sampoernauniversity.ac.id, muhammad.bhakti@sampoernauniversity.ac.id
}

\begin{abstract}
ABSTRAK
Aplikasi pengukur tingkat suara kini tersedia pada perangkat seluler di sistem operasi iOS dan Android. Aplikasi seluler ini dapat mengukur tingkat suara dalam desible (db). Saat dibandingkan dengan perangkat pengukur tingkat suara digital, hasil dari aplikasi tingkat suara ditemukan berbeda setelah beberapa kali pengujian. Aplikasi seluler yang sama pada perangkat seluler berbeda juga ditemukan hasil yang berbeda pula. Perlu dilakukan kalibrasi antara aplikasi dengan perangkat pengukur suara digital guna menghasilkan nilai yang mendekati atau sama. Metode ini nanti akan digunakan untuk memiliki data tingkat suara yang standar yang berasal dari perangkat loT untuk disimpan pada sebuah platform data.
\end{abstract}

Kata kunci: Perangkat Pengukur Tingkat Suara Digital, Aplikasi Pengukur Tingkat Suara, Kalibrasi.

\begin{abstract}
Sound meter mobile applications are available for mobile device iOS and Android operating systems. These mobile apps are able to measure sound level in decible (db) meter. Compare with a Digital Sound Meter device, results from sound meter app found different after few tests. Same mobile apps with different mobile devices found different results as well. Requires to do calibration between mobile apps and sound meter digital device to produce decible values those are close or the same. This method will be later used for having standard sound level data comes from loT devices to be stored on a data platform.
\end{abstract}

Keywords: Digital Sound Meter Device, Sound Meter Mobile App, Calibration.

\section{PENDAHULUAN}

Aplikasi pengukur tingkat suara pada ponsel berbasis sistem operasi iOS dan Android dijumpai beragam pada Apple App Store maupun Google Play. Sebuah aplikasi dengan fitur ini dibangun dan dikembangkan tentu diharapkan untuk memberi manfaat kepada pengguna aplikasi tersebut.

Pemilihan sistem operasi ponsel pintar iOS pada penelitian kali ini yaitu guna mendapatkan data yang lebih homogen dari 1 produsen ponsel Apple saja bila dibandingkan dengan platform

http://ejournal.urindo.ac.id/index.php/TI
Android yang memiliki ekosistem terbuka dengan multi produsen [4], lebih beragam merek dan beragam tipe.

Dari beberapa jenis tingkat tekanan bunyi atau pembobotan frekuensi pada pengukuran tingkat suara yang telah ditemukan dan digunakan, tingkat tekanan bunyi jenis $A$ weighting ( $\mathrm{dBA})$ adalah yang paling umum digunakan [1] di berbagai bidang. Pembobotan frekuensi tipe A-weighting ini juga yang digunakan pada penelitian ini. 
Pengukuran tingkat suara kerap digunakan terkait Keselamatan Kesehatan Keamanan Kerja (K3) [8]. Adapun pengukuran tingkat suara saat ini lebih menitikberatkan pada pengukuran tingkat suara pada lingkungan maupun kawasan [2] yang memiliki standar berbeda bila dibandingan dengan K3.

Regulasi tingkat suara dalam skala dBA telah diatur oleh Pemeintah baik untuk peruntukan lingkungan kegiatan [7] maupun kendaraan bermotor [6] dengan metode pengukuran yang juga telah ditentukan.

Aplikasi pengukur tingkat suara pada ponsel perlu dilakukan kalibrasi dengan perangkat pengukur suara digital yang digunakan sebagai referensi untuk mendapatkan nilai yang mendekati atau sama.

Metode kalibrasi ini di kemudian hari akan digunakan untuk dapat juga mendapatkan data tingkat suara yang mendekati atau sama, yang berasal dari loT yang juga menggunakan mikrofon seperti ponsel, untuk kemudian data tersebut dapat disimpan dan diolah pada sebuah platform data secara otomatis.

\section{METODE}

Di bawah ini merupakan metode penelitian yang digunakan saat ini:

\section{Survei Kuantitatif}

Terdapat 2 buah perangkat ponsel pintar Apple iPhone, 1 buah tablet Apple iPad dan 1 perangkat Pengukur Tingkat Suara Digital Extech Instruments digunakan. Proses perekaman data dilakukan pada bulan Januari 2020 lalu sebanyak 7 dan 10 kali, data didokumentasikan dengan cara mengambil foto layar setiap perangkat dan disalin menggunakan aplikasi Microsoft Excel untuk kebutuhan pengolahan data dan kemudian dianalisis.

\section{HASIL}

Penentuan Perangkat

http://ejournal.urindo.ac.id/index.php/TI
Saat ini hanya terdapat 1 alat Pengukur Tingkat Suara Digital Extech Instruments tipe 407732 yang digunakan dan dijadikan sebagai referensi perangkat bagi ponsel.

Tersedia pula 2 ponsel Apple iPhone (1 buah Apple iPhone 6s Plus, dan 1 buah Apple iPhone 5s), serta 1 buah tablet Apple iPad Mini 3 saja yang digunakan untuk membandingkan tingkat suara. Tertampil pada tabel 1 berikut ini mengenai informasi rinci tiap perangkat yang dimiliki:

\begin{tabular}{ccccc}
\hline Keterangan & $\begin{array}{c}\text { EXTECH } \\
\text { Instruments } \\
\mathbf{4 0 7 7 3 2}\end{array}$ & $\begin{array}{c}\text { APhone } \\
\text { 6s Plus }\end{array}$ & $\begin{array}{c}\text { APhone } \\
\mathbf{5 s}\end{array}$ & $\begin{array}{c}\text { iPad } \\
\text { Mini 3 }\end{array}$ \\
\hline $\begin{array}{c}\text { Sistem } \\
\text { Operasi }\end{array}$ & Bawaan & iOS 13.3 & iOS 12.4.4 & iOS 12.4.4 \\
Mikrofon & Bawaan & Internal & Internal & Internal \\
Aksesoris & $\begin{array}{c}\text { Busa Perisai } \\
\text { Angin }\end{array}$ & Tidak Ada & Tidak Ada & Tidak Ada \\
\hline
\end{tabular}

Tabel 1. Informasi Rinci Perangkat

Sistem operasi yang digunakan pada Apple iPhone 6s Plus berbeda dengan Apple iPhone 5s dikarenakan iPhone $5 \mathrm{~s}$ tidak lagi mendukung terinstalasinya sistem operasi iOS 13 . Sedangkan sistem operasi terbaru untuk tablet Apple iPad yakni iPadOS, yang juga tidak didukung oleh Apple iPad Mini 3 yang saat ini digunakan. iPad Mini 3 hanya dapat menggunakan sistem operasi iOS 12.

\section{Penentuan Piranti Lunak}

Perangkat Pengukur Tingkat Suara Digital Extech Instruments tipe 407732, menggunakan piranti lunak dasar yang telah tertanam di dalam internal perangkat. Piranti lunak ini tidak dapat dimutakhirkan secara mandiri.

Piranti lunak pada ponsel dan tablet menggunakan NIOSH Sound Level Meter (SLM) versi 1.2.1.39. Aplikasi ini hanya tersedia khusus untuk sistem operasi iOS dan tersedia di App Store. 


\section{Pengujian Awal}

Pengambilan data dilakukan sebanyak 7 kali di dalam ruangan dari perangkat-perangkat yang tersedia. Semua perangkat saat penangkapan data mengarahkan mikrofon ke atas untuk dapat menangkap suara, aktif dan berjalan selama 1 menit terlebih dahulu, data kemudian diambil dengan cara mengambil diambil gambar layar menggunakan kamera ponsel lain.

Proses pengambilan data ini memiliki hasil seperti tertera pada tabel 2 berikut:

\begin{tabular}{ccccc}
\hline$\#$ & $\begin{array}{c}\text { EXTECH } \\
\text { Instruments } \\
\mathbf{4 0 7 7 3 2} \text { (dBA) }\end{array}$ & $\begin{array}{c}\text { APPLE } \\
\text { iPhone 6s } \\
\text { Plus (dBA) }\end{array}$ & $\begin{array}{c}\text { APPLE } \\
\text { iPhone 5s } \\
\text { (dBA) }\end{array}$ & $\begin{array}{c}\text { APPLE } \\
\text { iPad Mini 3 } \\
\text { (dBA) }\end{array}$ \\
\hline 1 & 47,7 & 63 & - & - \\
2 & 49,2 & 55,5 & - & 50,3 \\
3 & 40,4 & 40 & - & 39,4 \\
4 & 41,2 & - & 41,1 & 41,4 \\
5 & 42,6 & - & 41,1 & 48,6 \\
6 & 53,3 & 50,6 & 51,2 & - \\
7 & 46,9 & 51,1 & - & 51,7 \\
\hline
\end{tabular}

Tabel 2. Hasil Pengujian Awal

Hasil dari tabel tersebut kemudian diambil nilai rata-rata guna mendapatkan gambaran awal perbedaan nilai dari tiap perangkat. Hasil ratarata pengujian tergambarkan pada grafik berikut ini:

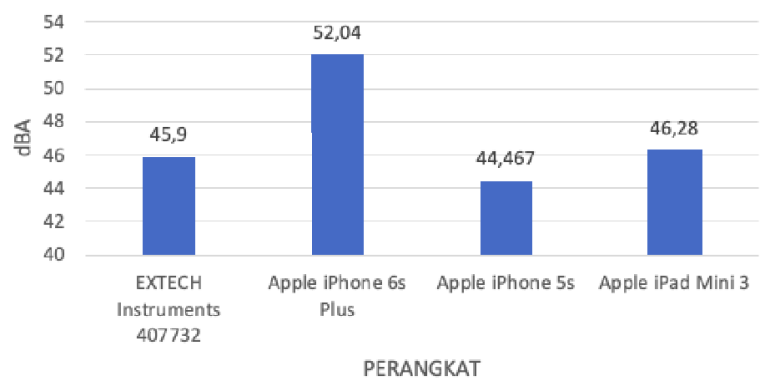

Gambar 1. Hasil Rata-Rata Pengujian Awal
Dijumpai perbedaan sangat signifikan pada Apple iPhone 6s Plus dengan perbedaan sebesar 6,14 dBA dengan nilai referensi perangkat EXTECH Instruments 407732. Perbedaan juga dijumpai pada Apple iPhone $5 s$ di $-1,433 \mathrm{dbA}$, sedangkan perbedaan paling minim terdapat pada Apple iPad Mini 3 di 0,38 dBA.

Hasil uji sederhana seperti ini yang kemudian dijadikan patokan bahwa hasil dari aplikasi Sistem Pengukur Tingkat Suara begitu berbeda, maka dari itu peran penyelarasan konfigurasi dan kalibrasi sangat diperlukan.

\section{Penyelarasan Konfigurasi}

Usai mempelajari berbagai konfigurasi yang tersedia pada Perangkat Pengukur Tingkat Suara Digital EXTECH Instruments 407732 dan aplikasi NIOSH SLM. Maka konfigurasi kedua perangkat perlu diselaraskan guna meminimalisir perbedaan keluaran data yang dihasilkan.

Fitur dan konfigurasi yang tersedia pada aplikasi NIOSH SLM ditemukan lebih banyak dibandingkan perangkat EXTECH Instruments 407732.

Tertera pada tabel 3 berikut ini adalah konfigurasi yang ditemukan dapat untuk diselaraskan antara aplikasi dan perangkat.

\begin{tabular}{cccccc}
\hline & $\begin{array}{c}\text { EXTECH } \\
\text { Instruments } \\
\mathbf{4 0 7 7 3 2}\end{array}$ & $\begin{array}{c}\text { APhone } \\
\text { 6s Plus }\end{array}$ & $\begin{array}{c}\text { iPhone } \\
\text { 5s }\end{array}$ & $\begin{array}{c}\text { iPad } \\
\text { Mini 3 }\end{array}$ & Catatan \\
\hline $\begin{array}{c}\text { Pembobotan } \\
\text { Frekuensi } \\
\text { Waktu } \\
\text { Respon }\end{array}$ & SLOW & FAST & FAST & FAST & Berbeda \\
\hline
\end{tabular}

Tabel 3. Penyelarasan Konfigurasi Perangkat

Pembobotan frekuensi kini telah diselaraskan dengan menggunakan pembobotan frekuensi A dan waktu respon yang digunakan adalah waktu respon Fast (cepat) pada keseluruhan perangkat yang digunakan pada penelitian ini. 


\section{Proses Pengamblan Data}

Dari 4 perangkat yang tersedia, Apple iPad Mini 3 tidak disertakan lagi untuk keseragaman perangkat lebih ke ponsel, dan dirasa lebih obyektif bila menggunakan lebih dari 1 tipe tablet iPad.

Saat pengambilan data berlangsung, keseluruhan perangkat disandarkan dengan mikrofon menghadap ke atas untuk memastikan mikrofon tidak terhalang dengan sumber suara. Serupa dengan pengujian awal.

Proses penangkapan suara dilakukan di dalam ruangan, guna mengurangi faktor angin yang mungkin bergemuruh dan mempengaruhi kualitas penangkapan tingkat suara. Perangkat EXTECH Instruments 407732 dilengkapi dengan busa perisai angin guna melidungi mikrofon, sementara ponsel Apple iPhone dengan mikrofon internal tidak.

Ketiga perangkat diaktifkan dan dapat mulai menangkap dan mengukur tingkat suara. Ketiga perangkat diaktifkan untuk mulai menangkap suara dalam ruangan minimum 60 detik.

Usai 1 menit berlangsung, data tingkat suara kemudian ditangkap dengan cara mengambil gambar melalui kamera ponsel guna menghasilkan data yang akurat dan terdokumentasi. Tertera pada gambar berikut ini.

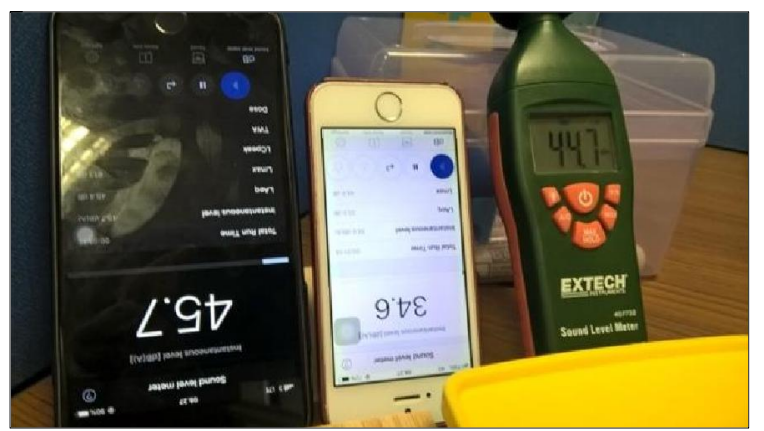

Gambar 2. Proses Pengambilan Data

Pada tanggal 24 Januari 2020 lalu, dilakukan 10 kali pengambilan data untuk kemudian dikumpulkan dan diteliti. Berikut ini adalah hasil survei dari proses pengambilan data tersebut.

\begin{tabular}{|c|c|c|c|c|c|}
\hline \multirow[t]{2}{*}{$\#$} & \multirow{2}{*}{$\begin{array}{c}\text { EXTECH } \\
\text { Instruments } \\
\mathbf{4 0 7 7 3 2} \text { (dBA) } \\
\text { Nilai }\end{array}$} & \multicolumn{2}{|c|}{$\begin{array}{c}\text { APPLE } \\
\text { iPhone 6s Plus } \\
\text { (dBA) }\end{array}$} & \multicolumn{2}{|c|}{$\begin{array}{l}\text { APPLE } \\
\text { iPhone 5s } \\
\text { (dBA) }\end{array}$} \\
\hline & & Nilai & Perbedaan & Nilai & Perbedaan \\
\hline 1 & 45,2 & 41,6 & $-3,6$ & 31,3 & $-13,9$ \\
\hline 2 & 44,6 & 41,7 & $-2,9$ & 30,9 & $-13,7$ \\
\hline 3 & 43,5 & 41,3 & $-2,2$ & 29,6 & $-13,9$ \\
\hline 4 & 44,7 & 42,3 & $-2,4$ & 31,5 & $-13,2$ \\
\hline 5 & 44,6 & 42,1 & $-2,5$ & 29,9 & $-14,7$ \\
\hline 6 & 45,1 & 42 & $-3,1$ & 30,4 & $-14,7$ \\
\hline 7 & 45,4 & 44,7 & $-0,7$ & 32,3 & $-13,1$ \\
\hline 8 & 44,7 & 45,7 & 1 & 34,6 & $-10,1$ \\
\hline 9 & 46,3 & 47,7 & 1,4 & 34,9 & $-11,4$ \\
\hline 10 & 45,9 & 40,2 & $-5,7$ & 27,7 & $-18,2$ \\
\hline
\end{tabular}

Tabel 4. Hasil Survei Pasca Penyelarasan

Dari data yang tertampil pada tabel kemudian dipresentasikan dalam bentuk grafik guna memudahkan analisa. Ditemukan bahwa kedua Apple iPhone memiliki pola yang mendekati sama meskipun data dari tangkapan suara berbeda jauh.

Dari 10 kali pengujian, didapatkan hanya 2 kali saja data pada EXTECH Instruments 407732 mendekati sama dengan aplikasi NIOSH SLM pada Apple iPhone 6s Plus dengan perbedaan hanya 0,7 dan 1 dBA. Tampak pada gambar berikut ini.

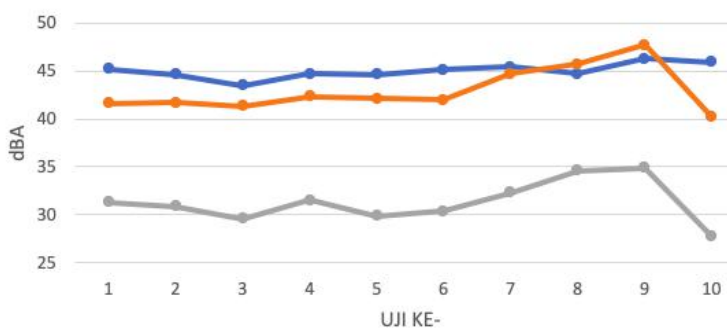

EXTECH Instruments 407732 Apple iPhone 6s Plus —Apple iPhone 5s

Gambar 3. Hasil Survei Pasca Penyelarasan 


\section{SIMPULAN}

1. Keluaran data dari tiap perangkat ponsel tetap menunjukkan perbedaan nilai meski ragam perbedaan telah diminimalisir dan konfigurasi telah diselaraskan. Perlu diteliti lebih lanjut mengenai jenis mikrofon yang tertanam pada masing-masing perangkat.

2. Proses kalibrasi dilakukan dengan data pada sumber suara yang memiliki masukan bervariatif meskipun sudah dilakukan di dalam ruangan.

3. Variabel yang terdapat pada aplikasi Pengukur Tingkat Suara ditemukan jauh lebih kompleks bila dibandingkan pada Perangkat Pengukur Tingkat Suara Digital yang digunakan pada penelitian ini. Perlu dikaji lebih lanjut semua fitur yang tersedia di dalamnya.

4. Aplikasi Pengukur Tingkat Suara yang telah terinstalasi tetap memerlukan proses kalibrasi dengan instrumen lain yang juga telah memenuhi standar sebelum digunakan guna mendapatkan hasil rekam data yang lebih baik di proses perekaman data selanjutnya.

\section{DAFTAR PUSTAKA}

[1]. Department of Environment and Science The State of Queensland. (2020). Noise Measurement Manual. Retrieved April 12, 2020, from https://environment.des.qld.gov.au/_data/a ssets/pdf_file/0027/88560/eis-tm-noisemeasurement-manual.pdf.

[2]. Hidayat, A. D., Sudibya, B., \& Waluyo, C. B. (2019). Pendeteksi Tingkat Kebisingan berbasis Internet of Things sebagai Media Kontrol Kenyamanan Ruangan Perpustakaan. Avitec, 1(1). doi: 10.28989/avitec.v1i1.497

[3]. FLIR Systems. (2014). Extech Instruments Digital Sound Level Meter Model 407732 User Guide. Retrieved April 7, 2020, from http://www.extech.com/products/resources/ 407732_UM-en.pdf. 
[4]. Kardous, Chucri A. \& Shaw, Peter B. (2014) So How Accurate Are These Smartphone Sound Measurement Apps? Retrieved April 7, 2020, from https://blogs.cdc.gov/niosh-scienceblog/2014/04/09/sound-apps/.

[5]. L. Laura Anastasi, P. Redi Kristrian. (2018). Rancang Bangun Sound Level Meter Menggunakan Sensor Suara Berbasis Arduino Uno. Jurnal IImu Dasar, 19 (2), 111-116.

[6]. Menteri Lingkungan Hidup dan Kehutanan Republik Indonesia. (2019). Peraturan Menteri Lingkungan Hidup dan Kehutanan Republik Indonesia Nomor: P.56/MENLHK/SETJEN/KUM.1/10/2019 tentang Baku Mutu Kebisingan Kendaraan Bermotor Tipe Baru dan Kendaraan Bermotor yang Sedang Diproduksi Kategori M, Kategori $N$, dan Kategori L.
[7]. Menteri Negara Lingkungan Hidup. (1996). Keputusan Menteri Negara Lingkungan Hidup Nomor: KEP-48/MENLH/11/1996 tentang Baku Tingkat Kebisingan.

[8]. Sasmita, Aryo \& Elystia, Shinta. (2016). Evaluasi Tingkat Kebisingan Sebagai Upaya Pengelolaan Kesehatan dan Keselamatan Kerja (K3) di Unit PLTD/G Teluk Lembu PT. PLN Pekanbaru dengan Metode NIOSH. Jurnal Sains dan Teknologi Fakultas Teknik Universitas Riau, 15(2), 34-42. 